\title{
MANGROVE RESOURCE USES BY LOCAL COMMUNITY IN INDONESIA
}

\author{
Cecep Kusmana ${ }^{\mathrm{a}}$, Sukristijiono ${ }^{\mathrm{b}}$ \\ ${ }^{a}$ Departement of Silviculture, Faculty of Forestry Bogor Agricultural University (IPB) Bogor, \\ Indonesia-ckmangrove@gmail.com \\ ${ }^{b}$ National Oceanography Agency, Indonesia Institute of Science
}

\begin{abstract}
Indonesia is an archipelagic country of more than 17,504 islands (28 big islands and 17,475 small islands) with the length of coastline estimated at 95,181 km, which bears mangroves from several meters to several kilometers. They are estimated at 3.2 million hectares growing extensively in the five big islands (Java, Sumatra, Kalimantan, Sulawesi, Papua) with various community types comprising of about 157 species (52 species of trees, 21 species of shrubs, 13 species of lyana, seven species of palms, 14 species of grasses, eight species of herbs, three species of parasites, 36 species of epiphytes, three species of ferns). The mangroves resources in Indonesia involve the flora, fauna, and land resources which are needed for supporting many kinds of human needs, especially for local community living in surrounding mangroves. For centuries, the Indonesian people have traditionally utilized mangroves. The most significant value of mangrove utilization is the gathering of forest products, classified into timber and non-timber products. The timber refers to poles and firewood, charcoal, and construction materials (e.g. housing material and fishing gears); the latter include tannin, medicines, dye, nypa thatch and shingles, nypa sap for vinegar and winemaking, and food drinks. Traditional uses of mangrove forest products are mainly the direct utilization of the products, usually in small scale. Beside of those, local community are used to utilizing associated mangrove aquatic fauna for supporting their daily life as well as utilizing mangrove habitat for multipurpose uses through agroforestry techniques (silvofishery, agrosilvofishery, agrosilvopastoralfishery systems). So that, the good mangrove ecosystem serves luxurious both flora and fauna species (biodiversity) as well as their abundance for signicantly supporting the welfare of coastal community
\end{abstract}

Keywords: agroforestry techniques, biodiversity, fauna, flora, land resources, local community, mangrove

(Diterima: 14-11-2016; Disetujui: 14-12-2016)

\section{Introduction}

Mangrove is a group of plants growing along tropical to sub-tropical coastline that develop specialization to suit its environmental condition such as salinity and anaerobic soil (Snedaker, 1978). While according to Aksornkoae (1993), mangrove forest is halophyte species occurring along the tropical and subtropical coastlines between the highest tidal level and close to or higher than sea level. Generally, mangrove forest can be defined as a type of forest growing in intertidal zones (sheltered coastline, lagoon, river banks) that experienced flooding during high tide and free from flood during low tide and tolerate saline condition. Beside, mangrove ecosystem is a system comprising of organisms (plants and animals) that interact with their environment in a mangrove habitat.

Mangrove resources comprise of: (1) one or more plant species that are restricted to mangroves, (2) plant species growing in mangroves and non-mangroves habitats (3) mangrove-associated biota (terrestrial and marine, tree moss, mushroom, algae, bacteria, etc) that are permanent, semi-permanent, rarely occurring, frequent or restricted in mangroves habitat, (4) dynamic processes that are important for ecosystem maintenance, (5) mud flat found between forest fringes and the open sea, and (6) population live in and/or surrounding mangroves.Mangrove is one of the primary features of the coastal areas in Indonesia, and plays significant roles in coastal development. It consists of true mangrove plants and associated species numbering at different species sites by sites in the country (van Steenis, 1958).

Mangrove species itself consist of three groups (Tomlinson, 1984):

1. Major mangroves, are species that occur exclusively in mangrove habitat, have the ability to form pure stands, play major role in the structure of community, develop morphological specialization (aerial root system and viviparous reproduction) and special mechanisms for salt exclusion to suit mangrove environment. These include genera Avicennia, Rhizophora, Bruguiera, Ceriops, Kandelia, Sonneratia, Lumnitzera and Nypa.

2. Minor mangroves, are mangrove species that rarely form pure stands, thus morphologically do not have dominant role in community structure. Examples include Excoecaria, Xylocarpus, Heritiera, Aegiceras. Aegialitis, Acrostichum, Camptostemon, Scyphiphora, Pemphis, Osbornia and Pelliciera.

3. Mangrove associates, are mangrove species that associate with major and minor elements of mangroves such as genera Cerbera, Acanthus, Derris, Hibiscus, Calamus, etc.

Mangrove flora consists of tree, herb, ferm, palm, epiphyte, liana, algae, bacteria and fungi. According to Hutching and Saenger (1987), there are 20 families 
of mangroves widely known in the world, comprising of 30 genera with more than 80 species. However, in Indonesia, Kusmana (1993) reported that there are approximately 202 mangrove plant species comprising of 89 species of tree, 5 species of palm, 19 species of liana, 44 species of soil herbs, 44 species of epiphyte, and 1 species of fern. Out of the total 202 species, 43 species are true mangroves and the rest are associate mangrove.

\section{Uses of Mangroves Products}

The values and uses of the mangrove resources are various and of great importance to the socio-economic condition of Indonesia. However, some are intangible and little appreciated by most people especially the urban dwellers. The importance of mangroves derives both from the direct and indirect products, and from amenities provided by the mangrove within and beyond its boundaries. As source of products, Indonesian mangroves have been utilized under economic exploitation, especially for forestry and fisheries.

Traditionally, the mangrove ecosystem in Indonesia has been an important resource for the human coastal communities. At present, human communities within Indonesian mangrove environment often considered mangrove ecosystem as an area of hope for the future. Consequently, the utilization of both, direct and indi- rect mangrove products is oriented toward mangrove species for livelihood purposes.

Mangroves are highly beneficial, as they yield many valuable products, while also performing, freeof-cost, many important functions (e.g. support bird and other wildlife, support education etc.) that support the often dense coastal populations. Nevertheless, mangroves will continue to be utilized by coastal inhabitants for their economic gain at subsistence level.Some of the early uses of mangroves are associated with their direct and indirect products, which in Indonesia represent very old means of mangrove utilization deal with forestry, agriculture, fishery and cultural activities. The use of mangrove products (direct and indirect) for local consumption represents a very long practice in Indonesia (Tables 1, 2, 3).

\subsection{Directs Products}

\subsubsection{Forest Product}

The most significant value of mangrove utilization is the gathering of forest products, classified into timber and non-timber products. The timber refers to poles and firewood, charcoal, and construction materials (e.g. housing material and fishing gears); the latter include tannin, medicines, dye, nypa thatch and shingles, nypa sap for vinegar and wine-making, and food drinks. Traditional uses of mangrove forest products are mainly the direct utilization of the products, usually in small scale.

Table 1. Medicinal and other uses of some mangrove plant in Indonesia

\begin{tabular}{|c|c|c|}
\hline No & Species & Uses \\
\hline 1 & Acanthus ebracteatusVabl. & - Leaf juice applied to the scalp to preserve the hair \\
\hline 2. & Acanthus ilicifolius $L$. & $\begin{array}{l}\text { - Crushed fruit is said to make a good blood purifier and dressing for boils and } \\
\text { snake bite }\end{array}$ \\
\hline 3. & Acrostichumaureum $L$. & - Succulent fiddleheads are edible raw or cooked \\
\hline 4. & Acrostichumcorniculatum (L.) Blanco & - Bark and seed contains a fish poison. \\
\hline 5. & Avicennia alba BI. & $\begin{array}{l}\text { - Bark and seed contains a fish poison. } \\
\text { - Resinous substance used for birth control purposes. } \\
\text { - Ointment made from seeds useful for relieving smallpox ulceration. }\end{array}$ \\
\hline 6. & Avicennia marina (Forsk,) Vierh. & - Source of pollen and strong flavoured honey for supporting bee colonies \\
\hline 7. & Avicenniaofficinalis $L$. & - Seeds eaten after leaching and cooking. \\
\hline 8. & Bruguierragymnorrhiza (L.) Lamk & $\begin{array}{l}\text { - Bark used as seasoning for raw fish } \\
\text { - Pneumatophores used in planting rituals by burying tubers to ensure big growth } \\
\text { of the tubers. } \\
\text { - Charcoal from this species is a substitute for petroleum coke which is used in } \\
\text { manufacturing calcium carbide and ferroalloys which in turn are utilized in } \\
\text { various chemical, plastic, and metal industries. }\end{array}$ \\
\hline 9 & $\begin{array}{l}\text { Bruguierraparviflora (Roxb.) W.A. ex } \\
\text { Griff }\end{array}$ & $\begin{array}{l}\text { - Bark used as seasoning for raw fish } \\
\text { - Pneumatophores used in planting rituals by burying tubers so that tubers will } \\
\text { grow big. } \\
\text { - Charcoal from this species is a substitute for petroleum coke which is used in } \\
\text { manufacturing calcium carbide and ferroalloys which in turn are utilized in } \\
\text { various chemical, plastic, and metal industries. }\end{array}$ \\
\hline 10. & Bruguierrasexangula (Lour.) Poit & $\begin{array}{l}\text { - Young leaves, fruit embryos, centre of radicals are cooked and eaten as vege- } \\
\text { table } \\
\text { - Fruit chewed as substitute for betel } \\
\text { - Lotion from the fruit is used as medication for sore eyes } \\
\text { - Leaves contain alkaloids that are tumour inhibitors } \\
\text { - Roots made into incense wood. }\end{array}$ \\
\hline 11. & Ceriopstagal (Perr.) C.B. Rob & $\begin{array}{l}\text { - Dye from the bark is used for colouring and preserving fishing nets and is } \\
\text { important in batik and mat-making in Java. } \\
\text { - Yield plywood adhesive }\end{array}$ \\
\hline
\end{tabular}




\begin{tabular}{|c|c|c|}
\hline & & - Bark infusion used as treatment for obstetric and haemorrhagic conditions. \\
\hline 12. & Excoecariaagallocha $L$. & $\begin{array}{l}\text { - Copious milky sap is exceedingly irritant and toxic; used as fish and arrow } \\
\text { head poison } \\
\text { - In the Philippines - causes blindness and used as medication for tooth ache. } \\
\text { - Decoction of leaves said to be used as cure for thrush in infants }\end{array}$ \\
\hline 12. & Lumnitzeralittorea (Jack) Voigt & - Fleshy fruits preserved \\
\hline 13. & OncospermafilamentosaBlume & $\begin{array}{l}\text { - Terminal buds for vegetable; } \\
\text { - } \text { Flowers added to rice as seasoning } \\
\text { - } \text { Leaves are boiled, dried, powdered and mixed with water for stomach upset }\end{array}$ \\
\hline 14. & Plucheaindica $L$. & $\begin{array}{l}\text { - Young leaves are edible } \\
\text { - Fruits scraped and eaten }\end{array}$ \\
\hline 15. & RhizophoramuncronataLamk & $\begin{array}{l}\text { - Honey produced form the nectar } \\
\text { - Fruit is eaten }\end{array}$ \\
\hline 16. & Sonneratilacaseolaris (L.) Eng & $\begin{array}{l}\text { - Sap applied to skin as cosmetics. } \\
\text { - Roots used as natural carvings for decorative purposes. }\end{array}$ \\
\hline 17. & Xylocarpusmoluccensis (Lamk) Roem & $\begin{array}{l}\text { - Bark astringent and used as cure for diarrhea } \\
\text { - Oil from seed is applied to hair and serves as illuminant }\end{array}$ \\
\hline
\end{tabular}

Table 2. Traditional uses of mangrove plants in Eastern part of Indonesia (Maluku, Papua) (Sukardjo, 2007)

\begin{tabular}{ccc}
\hline No & Species & Uses \\
\hline 1 & Rhizophorastylosa & Firewood for cooking food, smoking fish, charcoal; tannins for fishing net
\end{tabular}
and line preservation; woody middle layer (between the bark and the pith) of prop and aerial roots for stringing fish to facilitate their transport; prop and aerial roots for making Thalassinaanomala traps; bark to enclose Scylla serrata bait (made up of crushed Sesarma mixed with mangrove mud); stakes for husking coconut; aerial roots for making plaited fish traps, and bows; timber for building, scaffolds, tool handles; poles for fish traps, boats, fence posts; charcoal.

2 Bruguieragymnorrhiza $\quad$ Firewood for cooking, smoking fish, cremation, charcoal; timber for scaffolds, boat-building, beams, rafters, purlins, furniture, tool handles, poles foe fence posts, fish traps, boats, tanning for fishing net and line preservation; stakes foe husking coconuts; dye saplings for making $T$. anomala traps.

\begin{tabular}{cll}
\hline 3 & Xylocarpusgranatum & Firewood, timber, fence posts, beams, poles and used medicinally \\
\hline 4 & Xylocarpusmoluccensis & Firewood, timber, fence posts, beams, pole \\
\hline 5 & Lumnitzeralittorea & Firewood, timber, fence posts, beams, poles, poles for fish traps, tool han-
\end{tabular}

\begin{tabular}{cll}
\hline 5 & Lumnitzeralittorea & $\begin{array}{l}\text { Firewood, timber, fence posts, beams, poles, poles for fish traps, tool han- } \\
\text { dles, canoe making, and medicine }\end{array}$ \\
\hline 6 & Terminaliacatappa & $\begin{array}{l}\text { Trunk used to make 'lali' (canoe-shaped drum, truncated at both ends for } \\
\text { transmitting messages); seed as food; poles for building; canoe making; }\end{array}$
\end{tabular}
transmitting messages); seed as food; poles for building; canoe making; used medicinally

\begin{tabular}{cll}
\hline 7 & Calophylluminophyllum & $\begin{array}{l}\text { Timber, boat-building (ribs); infusion of leaves as eyewash; oil from fruits } \\
\text { as liniment, hair-dressing oil; for making 'lali'; used medicinally }\end{array}$ \\
\hline 8 & Excoecariaagallocha & Medicine for curing leprosy.(According to Burkill (1935) Malays used to
\end{tabular}
place people suffering from the diseases in an empty house and light a small fire on which they would place wood of E. agallocha. The ensuing smoked is believed to have cured the patients, besides causing them intense pain); the sap is an irritant and is believed to cause blindness; used as medicine

\begin{tabular}{|c|c|c|}
\hline 9 & Heritieralittoralis & Firewood, timber, fence, spots, used as medicine \\
\hline 10 & Barringtoniaasiatica & $\begin{array}{l}\text { Dry fruits are used as floats for fishing lines; as fish poison; used as medi- } \\
\text { cine }\end{array}$ \\
\hline 11 & Barringtoniaracemosa & Fruits are used as fish poison \\
\hline 12 & Inocarpusfagiferus & $\begin{array}{l}\text { Fruits as food; young leaves as vegetables; buttress roots for making knife } \\
\text { handles }\end{array}$ \\
\hline 13 & Intsiabijuga & $\begin{array}{l}\text { Exceptionally dense, hard timber; considered sacred by Papuans; used for } \\
\text { beams; posts, canoes, yaqona (an infusion of pounded stem and/or root of } \\
\text { Piper methysticum) bowls, clubs, head rest; used for medicine }\end{array}$ \\
\hline 14 & Entadaphaseoloids & $\begin{array}{l}\text { Young stems are used as ropes; seeds as necklace; thicker stems may be } \\
\text { used as a source of water }-30-40 \mathrm{~cm} \text { sections of the cut stem }(5-7 \mathrm{~cm} \text { across) } \\
\text { can provide a good drink of water (Parham, 1972) }\end{array}$ \\
\hline 15 & Abrusprecatorius & $\begin{array}{l}\text { Seeds are used for making necklaces for tourist (as the seeds are extremely } \\
\text { poisonous, they are boiled beforehand to dissipate the poison and also to } \\
\text { prevent them from shrinking) }\end{array}$ \\
\hline 16 & Derris trifoliata & $\begin{array}{l}\text { Fish poison, stem for stringing fish, immobilizing crabs, trying up firewood; } \\
\text { used as medicine }\end{array}$ \\
\hline 17 & Pongamiapinnata & Poles for construction, used as medicine \\
\hline 18 & Clerodendruminerme & $\begin{array}{l}\text { Sap of leaves is used for washing dishes; used as fish poison; used as medi- } \\
\text { cine }\end{array}$ \\
\hline 19 & Vitextrifolia & Used as medicine \\
\hline 20 & Cerberamanghas & $\begin{array}{l}\text { Used as medicine (According to Heyne (1950), the leaves after 'reducing to } \\
\text { pulp by chewing, were employed for stuffing hollow teeth') }\end{array}$ \\
\hline
\end{tabular}




\begin{tabular}{cll}
\hline 21 & Thespesiapopulnea & Used for boat building (ribs), fruit is used as toy, also as medicine \\
\hline 22 & Hibiscus tiliaceus & $\begin{array}{l}\text { Dry stem is used as floats for gill nets; fibrous bark for making ropes, grass } \\
\text { skirts, straining yaqona (an infusion of pounded stem and/or root of Piper } \\
\text { methysticum), making noose of } T \text {. anomala traps, seed as medicine }\end{array}$ \\
\hline 23 & Derris spp. & Used as medicine \\
\hline 25 & Stenochlaenapalustris & Leaves are used as food, used medicinally \\
\hline 26 & Aspleniumsp & Used as medicine \\
\hline
\end{tabular}

Table 3. Current traditional and potential uses of some mangrove species in Java, Sumatra, Kalimantan and Sulawesi (Sukardjo, 2007)

\begin{tabular}{|c|c|c|c|}
\hline No. & Products & Species & Uses \\
\hline 1 & Tannin & $\begin{array}{l}\text { Most mangrove spp. but Ceriops } \\
\text { spp. give the best quality }\end{array}$ & $\begin{array}{l}\text { Leather manufacture, inks, plastics, boiler water, oil-well } \\
\text { drilling, formaldehyde glues, rust preventives, insecticides, } \\
\text { medicine. }\end{array}$ \\
\hline 2 & Dyes & Xylocarpusspp. & Dyeing fishnets, ropes, sails, textiles. \\
\hline 3 & Colouring & Ceriopsspp. & Colouring rice and tuba (local wine). \\
\hline 4 & Cellulose Xanthate & Rhizophora spp. & $\begin{array}{l}\text { Production of viscose rayon for textile materials, tire cords, } \\
\text { industrial belts, cellophanes }\end{array}$ \\
\hline 5 & Oil & Xylocarpus seeds & Burning and hairdressing ( FAO 1982) \\
\hline 6 & Food & $\begin{array}{l}\text { Bruguieraspp. } \\
\text { Ceriopsspp. } \\
\text { Avicenniaspp. }\end{array}$ & $\begin{array}{l}\text { Source of honey, bees wax, tea substitutes; leaves eaten as } \\
\text { vegetable (raw or boiled), seasoning for raw fish }\end{array}$ \\
\hline 7 & Foliage & Avicenniaspp. & Fodder for goat, cattle, livestock supplement \\
\hline 8 & Extractives & $\begin{array}{l}\text { Cerberaspp. } \\
\text { Ceriopsspp. } \\
\text { and other mangrove species }\end{array}$ & $\begin{array}{l}\text { Premature falling of hair, good dressing for boil and snake } \\
\text { bites, relieve small pox ulcerations, and sore eyes, inhibit } \\
\text { tumours, effective contraceptives, medication for toothache, } \\
\text { purgative, mosquito repellent }\end{array}$ \\
\hline
\end{tabular}

\subsubsection{Timber and wood products}

Mangrove forests are exploited due to their valuable trees that can be use for various purposes. Timber is the most important product from the Indonesian mangrove forests e.g. Bengkalis (Versteegh, 1951). Some of the important timber-producing mangrove species are Rhizophora spp., Bruguiera spp., Ceriops spp., Xylocarpus spp., Sonneratia spp., Avicennia spp., Lumnitzera spp. and Heritieralittoralis, due to their durability (hard) and heavy wood structure. All the species provide marketable prices at the local, national and international levels. Timbers from these species are used for poles, piles, ship building, crafts, tool handles, railroad ties, furniture, and for other construction materials.

\section{a. Firewoods}

Mangrove woods are still widely used as energy source by rural coastal communities in many islands of Indonesia. The role of mangroves as potential sustainable source of fuelwood is important to meet the increasing needs for wood energy. However, large scale commercial exploitation of mangrove for fuelwoods seems to be rare.

Firewood is one of the earliest known uses and at one time, it was the most important direct product of mangroves (Becking et al. 1922). Firewood production is mostly small scale, done by villagers, very often without any legal documents to back them up e.g. Muna Island. It is used for cooking daily family meals, but also for energizing home industries like brown- sugar and lime production in Java, BatuAmpar-West Kalimantan, Sulawesi, and salt production in Java and Bali.

\section{b. Charcoals}

Woods from mangrove forests are mainly harvested for charcoal production $(90 \%)$, such as in Sumatra (Boon, 1936). Among the mangroves, Rhizophora spp is preferred due to its high heating value. Basically, charcoal is firewood that appears under a slightly different form. However, charcoal offers some other uses which are lacking in uncarbonized firewood, for example as an ingredient in the dry cell industry and metallurgical works.

\section{c. Housing material and fishing gear}

To the rural coastal villagers in many islands of Indonesia, mangroves are among the most beneficial plants on earth. They occur abundantly near the villages and are very handy to be harvested to meet the needs for housing materials, household articles, as well as fishing gears.

Mangrove woods are widely used for housing construction by people who live in or close to the mangrove forests. Woods of various mangrove species can be used for different parts of the house. The quality of mangrove woods that are used for house construction by the mangrove dwellers, varied according to size and shape of the house.Ceriops species are the most durable of all mangroves, Rhizophora and Bruguiera 
are not as durable, but all three have been used for house construction, paving blocks and tool handles.

Various types of fishing gear are used by mangrove dwellers but only some that are constructed from mangrove woods. Most mangrove poles made from Rhizophora spp. And Bruguiera spp. are used to trap crabs. Drift gill-nets and winged set-bag are fish traps made from Rh.apiculata and Bruguiera spp.

\subsubsection{Non-Timber Forest Products}

Among the non-timber products derived from the mangrove forests are tannin, dye, medicine, nypa thatch and single, nypa sap for vinegar, wine making and food, and honey.

\section{a. Tannin and dye}

Among the non-timber products derived from the mangrove forests, tannin is very popular. The extraction of tannin from mangrove barks has been recorded in early 1900's, but never developed into industry. Most mangrove trees are rich in tannin, so they can tolerate sea water logging.

Among the species identified to contain high qualities of tannin are Rhizophoraapiculata, Rh. mucronata, Bruguieraparviflora and Xylocarpusgranatum (Bumarlong, 1976). Rhizophora spp. are the best producers of tannins followed byCeriops spp., but species of Bruguiera are only mediocre. Tannin has a variety of uses such as in the manufacture of ink, plastics, glue, etc. Yet, the extraction of this substance from mangrove barks seems to be negligible at present. However, the traditional use of mangrove bark for tannin is still practiced in Indonesia.

Another use of mangrove bark is in the manufacture of dyes. Dyes extracted from the bark of X. granatum are used in dying fish nets, ropes and textile (batik), while extract from Ceriopstagal is commonly used in colouring rice and local wine tuba, such as in North Sumatra. In recent years, with the development of substitute chemicals, the dependence on mangrove tannin has greatly declined. However, local people still like to use mangroves as a source of tannin to dye fishing nets, clothes and other fishing materials due to their easy extraction.

\section{b. Food and drink}

Although of minor importance, some food products may be tapped, directly or indirectly, from mangrove forests in Indonesia. Some mangrove plants are edible. Direct food products includes among others, the young seeds and the sap of the flowers stalk of $\mathrm{Ny}$ pafruticans, the young leaves, shoots and propagules of Avicennia marina, the fruits of Sonneratia alba and the propagules of Bruguieragymnorrhiza. The fruits of species Avicennia, Bruguiera, and Sonneratia are edible, and seeds of Heritieralittoralis are eaten with fish. Nypa palm is probably the most important food producer from the mangrove forests.

\section{c. Medicinal elements}

Some mangrove species have been used and reported to have medicinal purposes for traditional people (van Steenis and Kruseman, 1953). For example, the bark of Xylocarpus spp. is said to be valuable for curing diarrhea and as astringent; the leaves of Excoecariaagallocha for curing epilepsy; the leaf juice of Acanthus spp could relieve rheumatism, etc. Local fishermen in mangrove sites in Indonesia still boil mangrove leaves using water as cure for skin diseases.

\section{d. Fodder and green manure}

In Indonesia, mangrove forests often serve as partial range-lands. Cattle, goats, sheeps and buffaloes are the domestic animals commonly known to feed on mangrove foliage. Avicenniamarina leaves, for example, are important as a source for fodder. Mangrove leaves are excellent fodder for many domestic animals, e.g. sheeps, goats, buffalos, and cattles, such as those found in Cimanuk delta complex, northern coast of West Java. Stall feeding using mangrove leaves is practiced in Java (Sukardjo and Akhmad, 1982).

In term of nutritive value, mangrove leaves, rank among the best (Hamilton and Snedaker 1984). It should be pointed out that the fresh leaf may contain more nutrient elements than the litters. Mangrove leaves are used as green manure for the fish-ponds maintenance and ecological productivity of their substrates, e.g. in northern coast of West Java. Green manures from mangrove species of Avicennia spp. and Rhizophora spp. are very popular nutrient inputs to stabilized the productivity of waterlogged soils in many coastal areas in Indonesia.

\section{e. Thatch}

Thatch production from the fronds of Nypafruticans remains an important traditional industry in Indonesian mangroves (Heyne, 1950). Due to the somewhat dwindling supplies of fronds from the wild, villagers sometimes supplement the resource by planting these palms in their compounds, e.g. Banyuasin, South Sumatra. During fronds harvesting, villagers usually leave behind at least 2 leaves per tree to avoid defoliation. Fronds collected are dried, folded over a wooded rod or bamboo and stitched in place. These shingles are used as walling or roof materials throughout the fishing villages. The durability of these shingles ranges from 2 to 3 years.

\section{f. Honey}

Some species of mangroves are nectariferous plants. When flowering, the forests of Aegicerascorniculatum and Kandeliacandel appear a vast scene of whiteness, which lures swarms of bees to gather nectars. Apiculture in mangrove forests has not developed in Indonesia though there was some folk work in this field in some areas in Indonesia, e.g. SegaraAnakan, Cilacap. 


\subsection{Indirect Products}

Apart from forest products, mangroves resources yield aquatic products harvestable from the forest floor or substratum, and its creeks and channels, and waterways. The periodically inundated forest floor is a rich habitat for a good number of animals including fish, shrimps, molluscs and crabs, call as aquatic products, or fishery products. Others sources of indirect products came from bees, birds, reptiles, mammals and other fauna. Only some of these animal species are permanent mangrove dwellers, others enter into this tidal forest for food or shelter. Certain species of shrimps are mangrove dependent at least during part of their life cycle.

Fishes, molluscs and crustaceans are regularly caught and harvested by the local population for family consumption or sale in nearby markets using traditional fishing methods and gears made of mangrove wood, and a dugout canoe. Traditional fishing methods and traps are still used.

Studies on fishes caught in the Banyuasin mangrove, South Sumatra (Burhanudin, 1980) revealed that there are about sixty eight families represented and the most common species are; Mugilcephalus, Arius sp., Lutjanus spp., Leiognathus sp., Trichiurus spp., Gerres sp. Caranx sp., Siganus sp., Sillagosihama and Theraponjarbua (Sukardjo, 2004).

As to the benthic communities, about sixty five species of molluscs are known to occur in the mangroves of Indonesia with the following as the most common species with economic values: Anadara antiquate (cockle), A. granosa, Ostreaamasa, Crassosteaechinata (oyster),Geloinacoaxans, Telescopiumtelescopium and Terebralliapalustris. T. telescopium is a large sized gastropods which swarms in thousands in mangroves and can be used as food, and is sold in the local market.

The oysters and cockles are the species that have commercial values. A. granosa is the most common species associated with mangrove and is much preferred for consumption. Among the crustaceans, the reported edible species are Thalassinaanomala, Thalamitasp and Scylla serrata. They are sold in the market.

\section{Uses of Mangrove Habitats}

Human interference dealing with the uses of mangroves habitats concern with the conversion of mangrove forests into other land uses (agriculture, saltbeds, aquaculture and settlements/urbanization).

\subsection{Agriculture}

Coastal mangroves in Indonesia, due to their saline and anaerobic soils, have been traditionally thought to be marginally suitable for agriculture. However, with improvement in the amelioration of saline and acidic soils (Kanapathy, 1971), the development of salt- tolerant plant varieties and the ever increasing demand for arable land, mangrove forest was viewed as one of the major alternatives for increasing arable land in the country.

In South Sumatra, extensive stretches of mangrove forest have been reclaimed during the last few decades. The major use of the reclaimed land is for the establishment of cash crop plantations such as coconut, cocoa and oil palm.

The process of reclamation for agriculture involves digging the canal parallel to the shoreline and piling the dug materials up to form a bund on the outer bank of the canal. A number of canals are often dug perpendicular to the first and these lead to the sea to facilitate drainage during low tides through tidal outlets. The bund prevents sea water intrusion and the forest within the bund is then clear-felled, drained and left to fallow for several years to permit leaching of surface salts by freshwater runoffs and rain. At the Banyuasin Irrigation Scheme in South Sumatra, which is the major rice bowl of Sumatra, a continuous coastal bund of about $96 \mathrm{~km}$ was built to protect the important rice fields.

A major constraint in utilizing mangrove land for agriculture is the genesis of acid sulphate soils due to the presence of large amounts of pyrites. Mangrove soils are also highly saline that no crops (with the possible exception of coconuts) can tolerate. Consequently, yields are generally poor. The constraints to production are inhibition of plant growth due to unfavourable soil conditions and the sociocultural problem of tenancy farming and smallholding. Reclaimed land has to be drained, leached and limed (the hold process may take 3 to 5 years) before crops can be grow. In addition, occasional coastal storm hazard, periodic flooding, poor watershed practices, coupled with high reclamation costs pose further problems which reduce the potential agricultural suitability of mangroves. The combination of these problems has impeded further agriculture reclamation projects in South Sumatra and in West Kalimantan.

\subsection{Brackish WaterFish-Pond}

Fish landing in Indonesia has reached its maximum sustainable yield and fish production is not expected to increase in the future. These, along with the increasing demand for marine food resources in the country, have prompted the Government to take steps to supplement marine food production by promoting brackish-water aquaculture in coastal areas particularly in the mangrove. Under the present National Development Programme Plan, aquaculture will fast become an important utilization of the mangrove ecosystem.

\subsection{Salt-Beds}

As in the case of fishponds, the actual extent of saltbeds in Indonesia is difficult to establish with certainty. 
From various published reports, it appears that this type of mangrove conversion is mainly operating in Java, Bali and Madura, and certain parts of Indonesia, where there is a marked dry season for a certain period of the year. Potentially, salt-beds in Indonesia estimated to be 36,000 ha with 9 main areas of salt beds viz. Aceh, West Java, Central Java, East Java, Bali, NTB, NTT, South Sulawesi and Central Sulawesi. The total production estimated at 2006 to be 1,300,000 tonnes. In NTT and NTB, for instance, there are about 9,000 ha of salt-beds which have met with a complete failure. This was due to various environmental factors which apparently had been over looked by those responsible in advising the decision makers and the projects.

\subsection{Settlements}

In view of population pressures and the increasing demand for land, there is much development of coastal areas in the country. This can be readily seen on the northern coast of Java. In Jakarta for instance, Kapuk area is located in reclaimed mangrove area. Many small towns have emerged from traditional mangrove fishing villages. In Indonesia, the extent of mangroves converted for industrial, port and residential purposes have further increases for development.

\subsection{Ecotourism}

Mangroves are habitable forests. Many wildlife used mangrove forests as their habitat, as corridor for their passage, feeding, nesting and refuges. All are very attractive for nature sightseeing. Rivers, creeks, canals, and all waterways system in the mangroves are major forms for fishing and swimming recreations. During bad weather, all canoes are moved into the rivers and creeks to avoid damage by heavy seas and strong winds. Demand on mangrove forests natural history and their wilderness are high and represent an attractive biome in Indonesia.

Multiple uses have been developed in mangrove management programmes in Indonesia, which include recreational use and other outdoor activities. Mangrove is an evergreen woody plant and usually forms a beautiful landscape. It can be used for sightseeing purposes, e.g. Sinjai mangrove forest. Many modern life styles, look for mangroves, to conduct cultural activities, and tourism interests. The mangrove forest provides visitors with aesthetic enjoyment and fresh air as well as negative ion of oxygen in the forest areas.

\section{Potential Uses}

As natural resource, mangroves benefit mankind directly through their forest products (wood and nonwood) as well as through their free services or amenities. To the latter we must add maintenance of coastal systems against destructive natural forces such as high-energy wind and wave action, etc.

Under natural and undisturbed conditions, the mangrove forests act as seaward barrier against coastal erosion and at the same time help to build and extend the coastline through accretion (Macnae 1968 and van Steenis, 1958). Erosion often occurs following removal of mangroves as a result of human interference (Carter, 1959), e.g. Aceh. After the tsunami, demand for mangrove forests as natural barrier grow vastly, and as potential coastal forests for harmonized living with environment.

\subsection{Mangroves Conservation Area}

In view of the rapid rate of conversion of mangrove forests in Indonesia in recent years for various land uses, there is an urgent need to establish more mangrove conservation areas in the country. These mangroves are vital for the protection of human life and property against coastal and riverbank erosion, for preserving commercial and recreational fisheries, for scientific and educational study, for preserving rare and endangered species and habitats and for recreational purpose.

It is also reported that PulauDua Nature Reserve, MuaraAngke Wildlife Reserve, Rambut Island Wildlife Reserve, KepulauanSeribu National Park, Ujung Kulon National Park, Sembilang National Park, Lorenz National Park, Bituni Nature Reserve and Bali Barat National Park bear a mangrove within their areas.

\subsection{Mitigation}

All types of mangrove forest, with the exception of altered forests, demonstrate the ability to mitigate tsunami energy and force, reduce flow depth and velocity, and limit inundation areas. Healthy, undegraded natural mangrove forests offer good protection to coastal areas.

Notwithstanding the positive role many coastal forests have played, other mangrove forests proved to be effective against the tsunami waves. Evidence shows that mangrove forests functions failed where waves were very large, mangrove forest width was limited; or mangrove trees were widely spaced, of small diameter or without branches near the ground level.

Based on field observation, forest is proven to be able to reduce energy of tsunami or tidal wave. Utomo (2003), cited by Diposaptono and Budiman (2008), stated that mangrove forest with density of about $5 \%$, height of $5 \mathrm{~m}$ and width of $50 \mathrm{~m}$ could reduce tsunami height by $52 \%$, and tsunami energy by $38 \%$. The mangrove forest could also reduce the tsunami run-up distance above water level to $14 \%, 19 \%$ and $22 \%$ for shore slopes of 50,100 and 150 respectively. Similar research results were also confirmed by Harada and Kawata (2004) who reported that coastal forests, comprising mangrove, sago, casuarina, and coconut stand with density of 3000 trees per ha, average stem diame- 
ter of $15 \mathrm{~cm}$ and forest width of about $200 \mathrm{~m}$, could reduce wave height by approximately 50-60\%, and tsunami water speed by about 40-60\%. Mazda et al. (1997) had previously reported the effectiveness of mangrove forest in reducing tsunami energy. According to their research, 6 years old Kandeliacandel mangrove forest, growing in a strip of $1.5 \mathrm{~km}$, could decrease wave height from $1 \mathrm{~m}$ at the open sea to $0.05 \mathrm{~m}$ at the coast. Based on the research results described above, it is evident that forest vegetation, especially mangrove, could reflect, run away, and absorb the energy of tsunami.

\section{Reference}

[1] Aksornkoae, S., 1993. Ecology and management of mangroves. IUCN Bangkok, Thailand. pp. 176

[2] [Bakosurtanal] Badan Koordinasi Survey dan Pemetaan Nasional, 2009. Peta Mangroves Indonesia. Cibinong: Pusat Survey Sumber Daya Alam Laut Badan Koordinasi Survey dan Pemetaan Nasional.

[3] Becking, J.H., L.G.den Berger and H.W. Meindersma, 1922. Vloed of mangroveboschen in Ned.Indie. Tectona 15, pp.561-611.

[4] Boon, D.A., 1936. De inrichting van de vloorexploitatie in samenwerking kommende bosschen in de afdeeling Bengkalis, benevens eenige opmarkeningen omtret de samenstelling de rte plaatse vorkommende moerasbosschen. Tectona 29. pp.344-374.

[5] Bumarlong, A.A., 1976. Tannin from our mangrove species. Canopy 2 (4), pp. 1-9.

[6] Carter, J., 1959. Mangrove succession and coastal changes in S.W. Malaya. Trans. Inst. Br. Geogr. 26pp. 79-88.

[7] Diposaptono, S, Budiman, 2008. Hidup Akrab dengan Gempa dan Tsunami. PT Sarana Komunikasi Utama, Bogor

[8] Hamilton, L.S and S.C. Snedaker (eds.), 1984. Handbooks for mangrove areas management. IUCN-UNESCO. pp.123.
[9] Harada, K. and Y. Kawata,. 2004. Study on the Effect of Coastal Forest to Tsunamy Reduction. Annuals of Disaster Prevention, Research Institute of Kyoto Univ. No.47C

[10] Heyne, K, 1950. De nuttige planten van Netherlandsch Indie. Buitenzorg. 2vols.

[11] Hutching, P. and P. Saenger, 1987. Ecology of mangrove. University of Queensland Press, Queensland, Australia.

[12] Kanapathy, K., 1971. Studies on the reclamation of acid swamp soils. Malay. Agric. J. 48, pp. 33-46.

[13] Kusmana, C., 1993. A study on mangrove forest management based on ecological data in East Sumatra, Indonesia. PhD. Dissertation, Kyoto University, Japan.

[14] Macnae, W., 1968. A general account of the fauna and flora of mangrove swamps and forests in the Indo-West Pacific region. Advances in Marine Biology 6, pp.74-241.

[15] Mazda, Y., M. Magi, M. Kogo and P. Ng. Hong, 1997. Mangroves as a coastal protection from waves in the Tong King Delta, Vietnam. Mangroves and Salt Marshes 1, pp. 127-135.

[16] Snedaker, S.C., 1978. Mangrove: their value and perpetuation. Nature and Resources 14, pp.6-13.

[17] Sukardjo, S and S. Akhmad., 1982. The mangrove forests of Java and Bali. Biotrop Spec. Publ. (17), pp 113-126.

[18] Sukardjo, S., 2004. Fisheries associated with mangrove ecosystem in Indonesia: a view from a mangrove ecologist. Biotropia 23, pp.13-39.

[19] Sukardjo, S., 2007. Mangrove biodiversity: the socio economic and conservation perspective in Indonesia. Paper submitted to Wetland Ecology and Management.

[20] Tomlinson, P.B., 1984. The botany of mangrove. Cambridge University Press. UK.

[21] van Steenis, C.G.G.J., 1958. Ecology - the introductory part to the Rhizophoraceae. Flora Mal. 5, pp. 431-441.

[22] van Steenis, C.G.G.J and M.J. Kruseman, 1953. Select Indonesian medicinal plant. Org. Sc. Res. Indon. Bull. 18, pp.190.

[23] Versteegh, F., 1951. Proeve vaan een bedrijfsregeling voor de vloebosschen van Bengkalis. Tectona DLXLI, pp.202-258. 